\title{
Fertility variation among individuals in natural stands of Acacia leucophloea
}

\author{
V.N. Mutharaian",4, R. Kamalakannan², , V. Narmatha Bai', A. Mayavel2 , D.-Y. Kim³ and K.-S. Kang ${ }^{3,6 *}$ \\ Department of Botany, Bharathiar University, Coimbatore-641 046, India \\ 2 Institute of Forest Genetics and Tree Breeding (IFGTB), Coimbatore-641 002, India \\ 3 Department of Forest Sciences, Seoul National University, Seoul 08826, Republic of Korea \\ 4 Present Addresses: ENVIS Centre on Forest Genetic Resources \& Tree Improvement, IFGTB, Coimbatore-641 002, India \\ 5 Present Addresses: ITC R\&D Centre, Peenya Industrial Area I Phase, Bangalore - 560 058, India \\ 6 Research Institute of Agriculture and Life Sciences, Seoul National University, Seoul 08826, Republic of Korea
}

*) Corresponding author: Kyu-Suk Kang, E-mail: kangks84@snu.ac.kr, Phone: +82-2-880-4753, Fax: +82-2-873-3560

\begin{abstract}
Growth characteristics and fertility variations were evaluated at four natural stands of tropical arid zone species, A. leucophloea in southern India. Three stands (TNL 1, TNL 2 and PDM) were situated in dry upland regions while one stand (RKP) was at waterlogged site. The tree height and girth at breast height did not vary between stands in two years. Fertility variation (sibling coefficient, $\psi$ ) was estimated based on flowering abundance and fruit set collected for two consecutive years. Fruit production per tree was generally lower in the RKP stand than the other three stands. No year-to-year variation was observed on fruit set in all stands. Growth and flower production showed a weak-positive correlation in both years $\left(R^{2}=0.39\right.$ to 0.1$)$. The correlation to check if the larger inflorescence size, the higher number of fruit production was also failed. Male fertility variation did not vary much among stands $\left(\psi_{m}=1.28 \sim 1.62\right)$. Female fertility variation was low $\left(\psi_{f}=1.71 \sim 2.02\right)$ in the three stands situated in dry upland regions than the RKP stand $\left(\psi_{f}=4.09 \sim 4.16\right)$. The cumulative contribution of trees to the overall fertility was deviated from the ideal situation (equal contribution) in all stands, especially the RKP stand showed a skewed distribution $\left(R^{2} \leq 6.5\right)$. The effective population size was low in the RKP predicting a high genetic drift when compared with other sites. Similarly high group coancestry and low gene diversity were observed in the stand RKP. The implications of fertility variation on gene diversity of the species and future management of the natural stands were also discussed.
\end{abstract}

Keywords: Acacia leucophloea, fecundity variation, effective population size, gene diversity, sibling coefficient

\section{Introduction}

The genus of Indian Acacia encompasses a wide variety of species of which Acacia leucophloea (Roxb.) Willd. maintains a larger domain. A. leucophloea is one of the potential non-timber forest products of peninsular India and holds a larger natural distribution than other nations where the species occurs in its native ranges. A. leucophloea supports the rural livelihood by providing small scale uses such as fodder, fuel wood, small timber and shade for livestock pasture over centuries. The tree is extremely tolerant to heat and drought, however, its tolerance to salinity or alkalinity is conflicting. The species contributes to soil improvement through nitrogen fixation. Besides, it is reported to contain several medicinal properties (Parotta, 2001). Despite these facts, no significant effort has been initiated in the country to generate management strategies for sustainable utilization and conservation of the species. Moreover, woodlands of A. leucophloea face continuous destruction on a large scale year-by-year due to the conversion of land to other purposes. In this context, there arises a need to generate and share knowledge towards the development of a technological base for conservation and effective use of the genetic resources of the species.

Breeding system aspects of the species such as flowering pattern, abundance, stigma receptivity, floral visitors, legitimate pollinators, fruit set percent, etc. have not been investigated or reported until now. Based on quite a few reports published on reproductive biology of Indian Acacias (Mandal and Ennos, 1995; Tandon et al., 2001; Solomon Raju et al., 2006), it can be presumed that $A$. leucophloea is a favorable outcrosser. However, this has to be substantiated. Occurrence of high 
density and sometimes pure stands of this species are common features associated with most of the dry or degraded areas from central to southern India. But the differences in flowering and pod production across populations have not been reported elsewhere. These will have strong implications in germplasm collection, tree improvement and genetic conservation programs (Sedgley and Griffin, 1989).

As far as forest trees are concerned, viable natural stands are the starting point of domestication and a proper selection of plus trees from natural stands is obligatory for the successful operation of any tree breeding program (Gregorius and Muller, 1975). Tree growth is frequently the sole criterion for selection of seed stands (Varghese et al., 2008). Earlier, several researches have proved that fertility estimation of forest trees by assessing flower and fruit production for consecutive years seems to be a feasible approach for selecting good stands (Bila and Lindgren, 1998; Nikkanen and Ruotsalainen, 2000; Krouchi et al., 2004; Varghese et al., 2006; Kamalakannan et al., 2007). It is implicit that variation in flowering abundance has a strong influence on the genetic diversity of seed crops (Nunney, 2000; Vasudeva et al., 2004). Hence, the ideas obtained from fertility parameters will help in identifying elite parental genotypes that could supply a seed source in establishing new stands. Tree fertility is broadly defined as the relative number of successful gametes of an individual (Gregorious, 1989). It is usually measured by a sibling coefficient $(\psi)$ and by the fertility coefficient of variation (CV) (Kang et al., 2003). Though both of these measures indicate unequal contributions of genotypes to the next generation in forest tree populations, Kang et al. (2003) recommend the use of $\psi$, as this value is related to probability that gametes from the same parent or individuals are sibs in the progeny whereas the dispersion parameter $C V$ is not sensitive to that.

Documentation of fertility parameters within a breeding population is worthwhile because these parameters to a larger extent determine the genetic diversity. Male and female fertility variation in forest trees has been widely reported in seed orchards (El-Kassaby, 1995; Bila et al., 1999; Kang et al., 2004; Vasudeva et al., 2004; Kamalakannan et al., 2007) whereas seldom reported in natural stands (Linhart and Mitton, 1985; Krouchi et al., 2004). Such variation is due to the cumulative contribution by genotype of individuals, environmental factors as well as forest management practices (El-Kassaby and Cook, 1994; Bila and Lindgren, 1998). The main focus of fertility variation is to determine the effective population size because differential contribution of tree toward gamete production is a common feature in most tree populations. If a population has few fertile individuals, only genes from these individuals will be over-represented in the progeny population, thereby reducing the effective population size. This in turn increases relatedness and inbreeding (Lindgren et al., 1996). Therefore by making contributions as equal as possible among trees this relatedness can be minimized and genetic gain will be enhanced.

The main objectives of the present study are to evaluate the fertility variation in selected natural stands of $A$. leucophloea in southern India on the basis of flower and fruit production over a period of two consecutive years, and to estimate the effective population size and gene diversity of seed collected from the stands. The impact of fertility variation on growth and gene diversity of the species and the implication on future management and breeding were also discussed.

\section{Materials and Methods}

\section{Studied seed stands and species}

Natural stands of $A$. leucophloea across various latitudes in southern India were selected for this study. Thennilai 1 (TNL 1), Thennilai 2 (TNL 2) and Palladam (PDM) stands are located in dry regions exhibiting more or less similar rainfall patterns (Table 1). Among them TNL 1 and TNL 2 are separated by about one kilometer. Rayakavundanpudur (RKP) stand is at water-fed site receiving a high rainfall than the other three stands. In this location, the individuals of the species remain waterlogged for at least 3 months in a year. The average age of trees in the four stands is 40 to 60 years.

Acacia leucophloea is a small and medium-sized, deciduous thorny tree that could attain a height of $25 \mathrm{~m}$. The trunk is stout, dividing into several large diameter branches. In most cases, formation of clear bole is absent. The outer bark is yellowish brown to white and the inner bark is smooth, light red in colour, exfoliating in irregular scales. Leaves are bipinnate ( 2 to $6 \mathrm{~cm}$ long), leaflets range from 12 to 30 in pairs ( 3 to $6 \mathrm{~mm}$ long), obtuse and ciliate along the margins.

Flowers are yellow, borne in globose heads 6 to $9 \mathrm{~mm}$ in diameter arranged in terminal panicles that are of $30 \mathrm{~cm}$ in length. The pedicels are stout with a toothed ring of bracts. The calyx $(1.2 \mathrm{~mm})$ and corolla $(2.5 \mathrm{~mm})$ are prominent. Seeds are borne in characteristic pods which are of 10 to $20 \mathrm{~cm}$ long and 0.6 to $0.8 \mathrm{~cm}$ wide. Pods (fruits) are sessile, thin and flat covered with pale brown tomentum. Seeds (10 to 20/pod) are oblong, dark brown and measure about $6 \times 4$ in size.

Table 1

Information on location, specifics and climate of the study sites

\begin{tabular}{|c|c|c|c|c|c|c|c|}
\hline Location & Topography & Area (ha) & $\mathbf{N}$ & Latitude & Longitude & Annual rainfall (mm) & Annual temp. $\left({ }^{\circ} \mathrm{C}\right)$ \\
\hline TNL 1 & Well drained plain & 3.0 & 76 & $10^{\circ} 56^{\prime} 55^{\prime \prime} \mathrm{N}$ & $77^{\circ} 50^{\prime} 35^{\prime \prime} \mathrm{E}$ & $600-700$ & $22-42$ \\
\hline TNL 2 & Well drained plain & 1.7 & 54 & $10^{\circ} 56^{\prime} 51^{\prime \prime} \mathrm{N}$ & $77^{\circ} 50^{\prime} 11^{\prime \prime} \mathrm{E}$ & $600-700$ & $22-42$ \\
\hline RKP & Water-logging undulate plain & 1.0 & 42 & $10^{\circ} 30^{\prime} 34^{\prime \prime} \mathrm{N}$ & $77^{\circ} 43^{\prime} 20^{\prime \prime} \mathrm{E}$ & $800-1500$ & $24-40$ \\
\hline PDM & Well drained plain & 2.0 & 57 & $10^{\circ} 59^{\prime} 26^{\prime \prime} \mathrm{N}$ & $77^{\circ} 17^{\prime} 51^{\prime \prime} \mathrm{E}$ & $600-1200$ & $22-38$ \\
\hline
\end{tabular}




\section{Data collection}

The flower and fruit production in natural stands of A. leucophloea were observed and recorded for two consecutive years (2009 and 2010). Tree height was measured by a long pole marked at regular intervals. Girth at breast height (GBH) was measured at $1.3 \mathrm{~m}$ from the ground level using a measuring tape. The number of primary branches, the number of secondary branches and the number of tertiary branches of the representative primary branch were counted in each tree. The flowers per tertiary branch were recorded during the flowering months (late August to October) for all trees either by ocular estimation or by pulling down the representative primary branch using a clasp. In case of very high branches a binocular (Leica 42X) was used.

Similarly the number of fruits in respective trees was recorded during the period of January to March. The period of both flower and fruit recording slightly varied between the stands. The total numbers of flowers and fruits produced per tree were obtained by extrapolating the counts made on flowers and fruits (Kang and Lindgren 1998, Bila et al. 1999).

\section{Fertility variation estimation}

Each individual has a fertility value, the ability to transmit genes to the offspring. Fertility can be regarded as the progeny mothered or fathered by an individual relative to others in the population (Devlin and Ellstrand, 1990). The male and female fertility of a tree is considered to be proportional to the number of male and female gametes produced by the tree (Gregorius, 1989). Gender fertilities were assumed to the number of reproductive structures (male fertility as number of flowers and female fertility as number of fruits in this study) expressed as a proportion of all trees. Total fertility of a tree $\left(p_{i}\right)$ was taken as the average of the male $\left(m_{i}\right)$ and female $\left(f_{i}\right)$ fertilities of each tree.

Fertility variation was described by the sibling coefficient $(\psi)$. A sibling coefficient expresses the probability that two genes drawn randomly from the gamete gene pool originate from the same parent compared to the probability when the parents have equal representation. The $\psi$ is a standardized measure that does not depend on the census number of parent genotypes $(N)$, but only on how variable their fertility is. Thus the fertility of each parent is given as a fraction of all gametes. This concept was introduced by Kang and Lindgren (1999) as

$\psi=N \sum_{i=1}^{N} p_{i}^{2}$

where $N$ is the census number of parents in a population, $p_{i}$ is the probability that a gene in the offspring originates from parent $i$ (in other words it is the individual fertility of $i^{\text {th }}$ tree in the population).

From the above equation, a maternal sibling coefficient $\left(\psi_{f}\right)$ and a paternal sibling coefficient $\left(\psi_{m}\right)$ can be arrived as follows:

$\psi_{f}=N \sum_{i=1}^{N} f_{i}^{2} \quad$ and $\quad \psi_{m}=N \sum_{i=1}^{N} m_{i}^{2}$ where $m_{i}$ is the male fertility and $f_{i}$ is the female fertilities from parent $i$, respectively.

\section{Group coancestry and effective population size}

The average relatedness among the members of a population is described by group coancestry $(\Theta)$ which is the probability that two randomly sampled gametes contain the same gene (Cockerham, 1967). Following Lindgren and Mullin (1998), this probability is given by

$$
\Theta=\sum_{i=l}^{N} p_{i} \sum_{j=l}^{N} p_{j} \theta_{i j}=\sum_{i=l}^{N} \sum_{j=l}^{N} p_{i} p_{j} \theta_{i j}
$$

where $p_{i}$ and $p_{j}$ are the probabilities that genes sampled at random from the gamete pool originate from genotypes $i$ and $j$, respectively and $\theta_{i j^{\prime}}$ is the probability that genes sampled from genotypes $i$ and $j$ are identical by descent (i.e., coancestry between genotypes $i$ and $j$ ).

If different sexes among parents are considered, this expression can be divided into paternal, maternal components and an interaction term, so that

$$
\begin{aligned}
\Theta & =\sum_{i=1}^{N}\left(m_{i}+f_{i}\right) \sum_{i=1}^{N}\left(m_{i}+f_{i}\right) \theta_{i j} \\
& =\sum_{i=1}^{N} m_{i} \sum_{j=1}^{N} m_{i} \theta_{i j}+\sum_{i=1}^{N} f_{i} \sum_{j=1}^{N} f_{i} \theta_{i j}+2 \sum_{i=1}^{N} m_{i} \sum_{j=1}^{N} f_{i} \theta_{i j}
\end{aligned}
$$

In case if there is no correlation between genders in fertility, the last term in the above equation is zero. Assuming that genotypes unrelated and non-inbred, all pair-wise coancestries are equal to zero, and all self coancestries equal to 0.5.The group coancestry can thus be calculated from individual fertilities $\left(p_{i}\right)$ considering male $\left(m_{i}\right)$ and female $\left(f_{i}\right)$ fertilities as

$\Theta=0.5 \sum_{i=1}^{N} p_{i}^{2}=0.5 \sum_{i=1}^{N}\left(\frac{m_{i}+f_{i}}{2}\right)$

The status number $\left(N_{S}\right)$ can be considered as an effective population size) is the number of genotypes sampled from the reference population that would cause the same deviation in gene frequencies in the studied population (Lindgren and Mullin, 1998) as

$N_{s}=\frac{0.5}{\Theta}$

The relative status number $\left(N_{r}\right)$ can be used to relate to the actual number as

$$
N_{r}=\frac{N_{s}}{N}
$$

\section{Gene diversity}

Expected gene diversity $(G D)$ is equivalent to the expected heterozygosity in a population following random mating and is a function of group coancestry (Nei, 1973; Lacy, 1995). Gene diversity can be formulated as $G D=1-\Sigma q i^{2}$, where $q_{i}$ is the frequency of allele $i$ and the summation is over alleles at that locus. If all alleles are unique in a large source population (also 
known as the reference population) of unrelated and noninbred individuals, the gene diversity can be set to one and the gene diversity of the descendants, as a proportion of diversity in the source population, can be estimated as

$G D_{\text {parents }}=1-\Theta_{\text {parents }}=1-\frac{0.5}{N_{s \text { parents }}}$

It should be noted that group coancestry and status number are closely correlated to the loss of gene diversity relative to the source population. The decrease in heterozygosity compared to the reference population reflects the accumulation of coancestry and inbreeding associated with variation in fertility among parents.

\section{Data analysis and cumulative curve}

A correlation coefficient was calculated between growth character (height and GBH) and reproductive output (flower and fruit). As the number of flowers per inflorescence varied greatly, a correlation coefficient was also carried out against flower and fruit production by individual trees in all stands to check whether larger inflorescences produced large number of fruits. One-way ANOVA was performed for each floral trait in order to elucidate the differences between years as well as among stands. A stand-wise cumulative contribution of trees and the correlation coefficient between the cumulative contribution and the percentage of tree was computed for both years.

\section{Results}

\section{Growth and reproductive traits}

The analysis of variance for all traits exhibited significant differences among four stands of A. leucophloea in 2009 and 2010. As the growth of tree was relatively slow, the height and GBH did not have the distinct variation between populations (Table 2). Among populations, the average of tree height ranged $4.52 \mathrm{~m}$ at RKP and 5.42 mat TNL 2, while GBH ranged between $49.03 \mathrm{~cm}$ at TNL 1 and $62.94 \mathrm{~cm}$ at TNL 2 .

A considerable variation of flowering in primary branches was founded (Table 2). The stand RKP produced 3.43 primary branches in both years while TNL 2 produced 4.52 and 4.64 primary branches in 2009 and 2010. The grand mean for the trait was 3.97. The stands TNL 1 and TNL 2 exhibited higher number of primary branches than the grand mean.

The mean of inflorescence per primary branch ranged from 156.81 to 160.93 and 282.33 to 303.56 for 2009 and 2010 (Table 2). Among stands, TNL 2 was found to most excel for inflorescence per primary branch in both years. The flowers per tree exhibited considerable variation among stands. The stand TNL 2 recorded the highest number of flower in both years while the stand TNL1 recorded lowest flower production (Table 2). The stand TNL 1 showed high fruit set percent $(0.27 \%)$ in both years even though the number of flower/tree and the number of fruit/tree were intermediated. The stand TNL 2 showed highest flowers/tree and fruits/tree in 2009 and 2010. The stands TNL1 and TNL 2 were superior for fruits/tree, flowers/tree and fruit set percent compared to the other stands.

The coefficient of determination ( $R^{2}$ values) calculated between girth at breast height $(\mathrm{GBH})$ and flower production revealed positive and weak correlation for all stands in 2009 and 2010 (Figure 1), implying that tree growth would not be a constraint for flower production in A. leucophloea (see also Table 2). Similarly, no positive correlation was observed between inflorescence size and fruit set (i.e., the larger inflorescence size, the larger fruit set) for both years (Figure 2).

Table 2

A characteristic of growth traits (height and $\mathrm{GBH}$ ) and reproductive outputs (flower and fruit) in four natural stands of $A$. leucophloea in 2009 and 2010.

\begin{tabular}{|c|c|c|c|c|c|c|c|c|c|}
\hline Stand & Year & Height (m) & $\mathrm{GBH}(\mathrm{cm})$ & PriBr & Inf/Pri & Fruits/Infl & Flowers/tree & Fruits/tree & Fruit set (\%) \\
\hline \multirow[t]{2}{*}{ TNL 1} & 2009 & 5.04 & 49.03 & 4.00 & 175.30 & 5.68 & 381101 & 1013.78 & 0.27 \\
\hline & 2010 & & & 4.07 & 180.06 & 5.97 & 400091 & 1110.32 & 0.27 \\
\hline \multirow[t]{2}{*}{ TNL 2} & 2009 & 5.42 & 62.94 & 4.52 & 282.33 & 5.76 & 773856 & 1770.15 & 0.22 \\
\hline & 2010 & & & 4.64 & 303.56 & 5.92 & 838259 & 1990.78 & 0.22 \\
\hline \multirow[t]{2}{*}{ RKP } & 2009 & 4.52 & 54.10 & 3.43 & 156.81 & 2.5 & 402737 & 433.71 & 0.12 \\
\hline & 2010 & & & 3.43 & 160.95 & 2.62 & 430175 & 432.28 & 0.13 \\
\hline \multirow[t]{2}{*}{ PDM } & 2009 & 4.79 & 54.67 & 3.82 & 199.73 & 4.54 & 533768 & 994.65 & 0.18 \\
\hline & 2010 & & & 3.89 & 203.63 & 4.38 & 550535 & 1011.56 & 0.16 \\
\hline Grand mean & & 4.94 & 55.18 & 3.97 & 207.06 & 4.67 & 538815.3 & 1094.65 & 0.19 \\
\hline SE(d) & & 0.19 & 3.62 & 0.26 & 13.987 & 0.317 & 36820.9 & 79.144 & 0.01330 \\
\hline
\end{tabular}


Year 2009
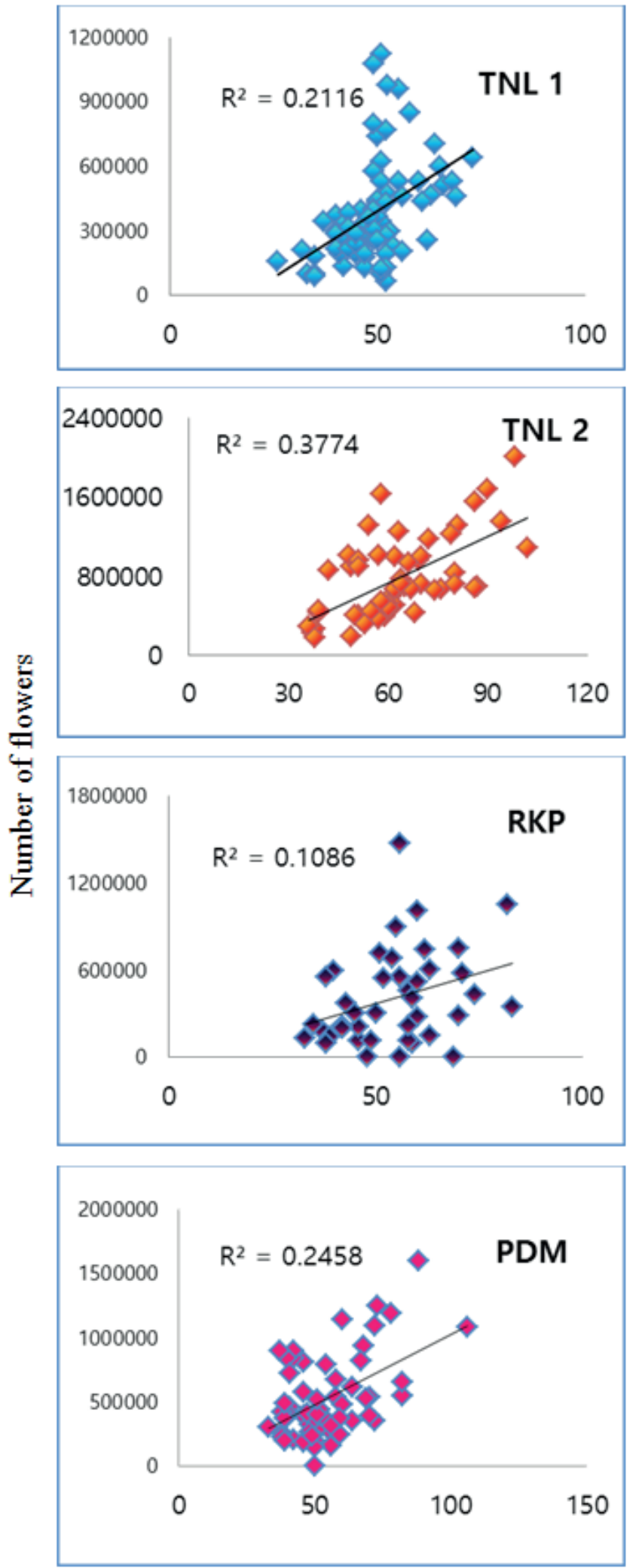

\section{Year 2010}
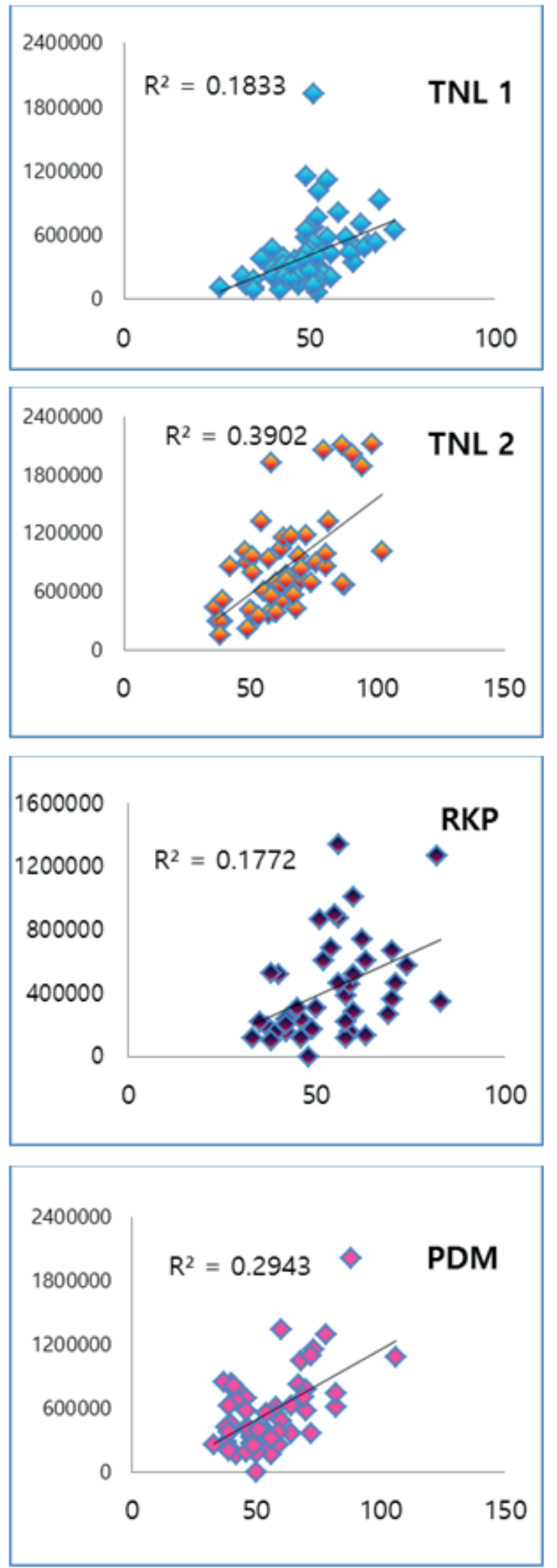

Girth at breast height $(\mathrm{GBH})$ 


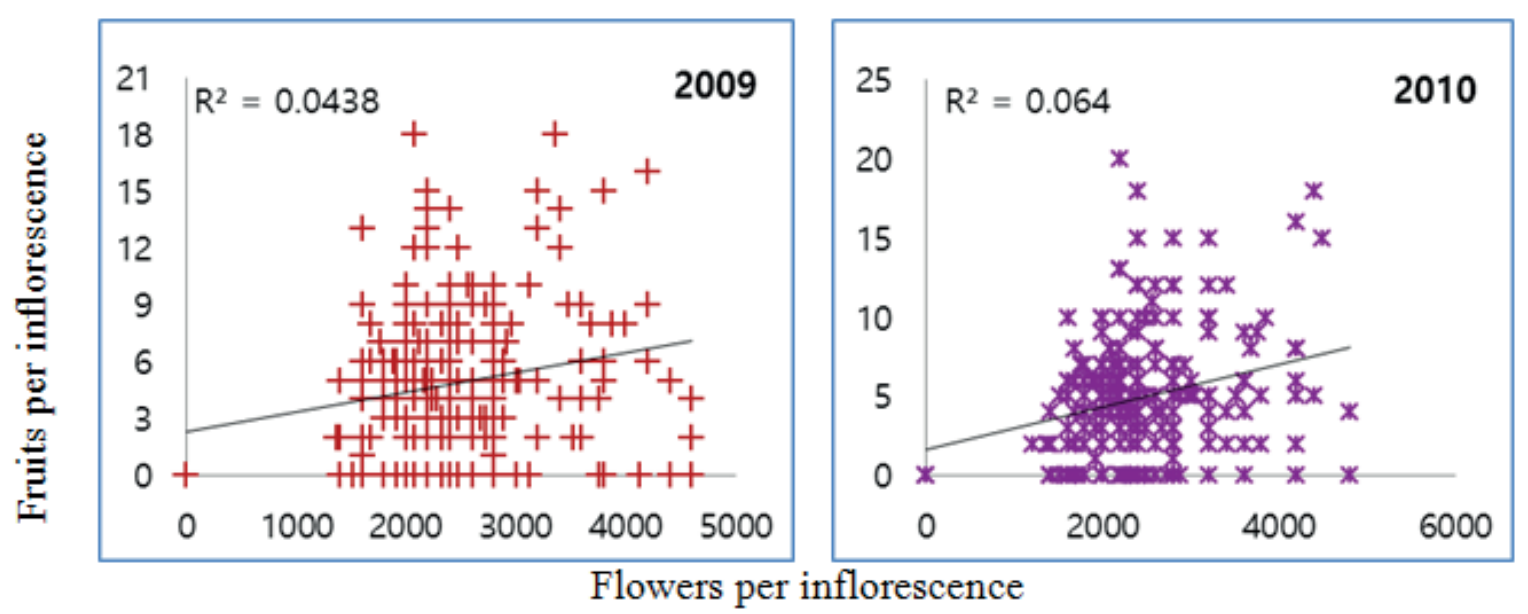

Figure 2

Correlation between flowers and fruits per inflorescence from a total of 229 individuals in four natural stands of $A$. leucophloea in 2009 and 2010.

\section{Flowering and fertility variation}

The percentage of flowering tree was very high ranged from $93 \%$ to $100 \%$ (Table 3 ). All trees produced flowers in the stands of TNL1 and TNL 2 in both years. In the stand RKP, seven and three trees did not produce any flower in 2009 and 2010, respectively, which would not contribute to transmit their genes to next generations.

Fertility variation estimated and expressed as sibling coefficients, varied from 1.28 to 4.16 among the natural stands during the study period (2009 and 2010). Male fertility variation $\left(\psi_{\mathrm{m}}\right)$ ranged from $1.28 \sim 1.62$ and did not vary much between years and among stands (Table 3 ). The female sibling coefficients were larger than the male sibling coefficients in all populations(Table 3), meaning that the variation of female fertility was larger than the variation of male fertility among individuals. The TNL 2 stand recorded very low female fertility variation $\left(\psi_{f}=1.71 \sim 1.90\right)$, and the RKP stand revealed the highest female fertility variation $(4.09 \sim 4.16)$. The combined sibling coefficients $(\psi)$ were more or less similar in two successive years (Table 3 ).

\section{Effective population size and gene diversity}

The effective population size $\left(N_{s}\right)$ of the RKP stand was low (10.26 and 10.08) in both years (Table 3 ), indicating that a quarter of the individuals in the population showed the same amount of dispersion of allele frequencies under random genetic drift or the same amount of inbreeding as the reference population. The TNL 1 stand showed comparatively higher effective population sizes $\left(N_{s}=43.13\right.$ and 41.48$)$ contributing effectively to seed production. The RKP stand showed the lowest $N_{s}$ in both years.

Table 3

Percent flowering, fertility variation, effective population size, group coancestry and gene diversity in natural stands of $A$. leucophloea in 2009 and 2010.

\begin{tabular}{|c|c|c|c|c|c|c|c|c|c|}
\hline \multirow[t]{2}{*}{ Stand } & \multirow[t]{2}{*}{$\begin{array}{l}\text { Survey } \\
\text { year }\end{array}$} & \multirow[t]{2}{*}{ Flowering (\%) } & \multicolumn{3}{|c|}{$\begin{array}{l}\text { Fertility variation } \\
\text { (sibling coefficient)* }\end{array}$} & \multirow[t]{2}{*}{$\begin{array}{l}\text { Effective pop. } \\
\text { size (Ns) }\end{array}$} & \multirow[t]{2}{*}{$\begin{array}{c}\text { Relative effective } \\
\text { pop. size (Nr) }\end{array}$} & \multirow[t]{2}{*}{ Group coancestry ( $(\Theta)$} & \multirow[t]{2}{*}{$\mathrm{GD}^{* *}$} \\
\hline & & & $\psi_{m}$ & $\psi_{f}$ & $\psi$ & & & & \\
\hline TNL 1 & 2009 & 100 & 1.37 & 1.76 & 1.44 & 43.13 & 0.56 & 0.012 & 0.98 \\
\hline$(N=76)$ & 2010 & 100 & 1.53 & 1.83 & 1.56 & 41.48 & 0.54 & 0.012 & 0.98 \\
\hline TNL 2 & 2009 & 100 & 1.28 & 1.71 & 1.42 & 31.41 & 0.58 & 0.012 & 0.98 \\
\hline$(N=54)$ & 2010 & 100 & 1.35 & 1.90 & 1.54 & 28.34 & 0.52 & 0.017 & 0.98 \\
\hline RKP & 2009 & 93 & 1.62 & 4.09 & 2.18 & 10.26 & 0.24 & 0.048 & 0.95 \\
\hline$(\mathrm{N}=42)$ & 2010 & 97 & 1.52 & 4.16 & 2.18 & 10.08 & 0.24 & 0.049 & 0.95 \\
\hline PDM & 2009 & 98 & 1.36 & 1.94 & 1.52 & 29.33 & 0.51 & 0.017 & 0.98 \\
\hline$(N=57)$ & 2010 & 98 & 1.42 & 2.02 & 1.61 & 28.12 & 0.49 & 0.018 & 0.98 \\
\hline
\end{tabular}




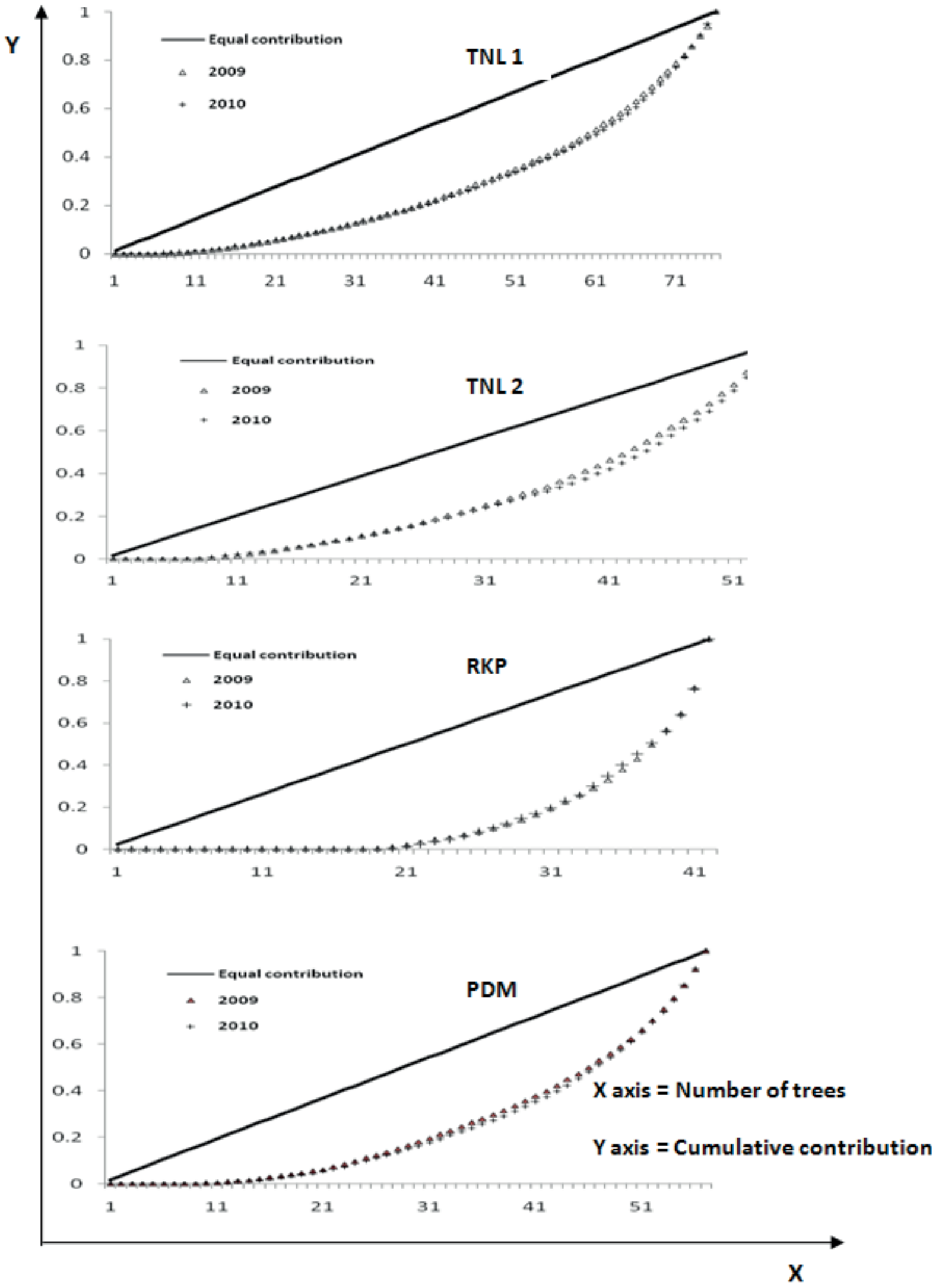

Figure 3

Cumulative contribution curve of individual trees to overall fertility estimates in four natural stands of $A$. leucophloea. 
Relative effective population sizes $\left(N_{r}\right)$ were similar among populations (about $50 \%$ ). The RKP stand showed the lowest relative effective population size $(24 \%)$. There were no significant differences in $N_{s}$ and $N_{r}$ between years. The values of group co-ancestry $(\Theta)$ in natural stands of $A$. leucophloea varied from 0.012 to 0.049 (Table 3). The highest $\Theta$ value was recorded in the RKP stand $(\Theta=0.049)$ and hence the lowest gene diversity $(G D)$ value of 0.95 was predicted. The value of $\Theta$ produced great impact on gene diversity as $G D=1-\Theta$. The other three stands showed similar values of $\Theta$ (about 0.11 to 0.12 ) and the gene diversity of 0.98 to 0.99 (Table 3 ). The group coancestry between years was also very similar in all stands.

\section{Cumulative contribution}

The cumulative contribution of trees to the overall fertility estimates per stand for 2009 and 2010 were expressed by the $\psi_{m}$ and $\psi_{f}$ values (Figure 3). A cumulative contribution curve describes the relative proportion of trees to the accumulative gamete contribution. In an ideal situation, that is expecting an equal contribution from each of the individuals (a condition where $\psi=1$ ), this cumulative curve attains a straight line. There was a large deviation in cumulative contribution from expectation in all stands. From Figure 3 , it could be inferred that three stands (TNL I, TNL 2, and PDM) showed a similar trend $\left(R^{2} \geq 0.85\right)$ in both years. Only the RKP stand showed a skewed distribution $\left(R^{2} \leq 6.5\right)$ in both years. It could thus be said that the RKP stand was much more deviated from the ideal situation compared to the other three stands.

\section{Discussion}

Natural stands of $A$. leucophloea in the present study share similar environmental conditions and hence exhibit similar developmental change, pollination mechanism and seed dispersal mode. There is lack of proper management, but trees grow profusely and thinning is rarely done in the stands. These stands are found in large numbers over generations in the arid and semi-arid regions of southern India. Tree improvement program of A. leucophloea is in high fragmentation in the country. Regarding the establishment and utilization of seed stands or seed orchards, many factors such as fertility, phenology and pollination should be surveyed.

\section{Growth and reproductive output}

If pollination does not act as a limiting factor, the fruit or seed production goes fairly as a function of plant size in most tree species (Crawley, 1997). From the girth class it is clearly indicated that $A$. leucophloea falls under the category of small to medium size trees. In general, a good correlation between tree dimension and reproductive capacity is expected because tree dimension is directly related to the factors that determine fertility such as tree age, tree vigor and local environmental conditions (Krouchi et al., 2004). In Ponderosa pine, Linhart and Mitton (1985) observed that both male and female production increased with increasing diameter. On contrary, Debain et al.
(2003) found a linear correlation between tree dimension and fertility only for those trees that grow on the margin of stand and not for those within stand.

Similarly, a weak correlation was observed between the circumference and the number of male branches in natural stands of Cedrus population (Krouchi et al., 2004). In concurrence with these, a weak positive correlation was obtained between $\mathrm{GBH}$ and flower production in all stands as well as for both years in the present investigation. Krouchi et al. (2004) further argued that dimension or girth class did not serve as a good predictor of female fertility in the case of larger trees.

Teak trees in natural stands are bearing more number of flowers at primary branches (PriBr) and hence more number of fruits (Varghese et al., 2008). This is also evident in the case of A. leucophloea as it produced more number of PriBr in all study locations. Various parameters such as flowering primary branches (PriBr), number of inflorescences per primary branch (Infl/Pri), fruits per inflorescence, fruit set percent, flower and fruit production per tree varied considerably across stands. A similar variation in such traits had been reported in natural stands of Cedrus atlantica (Krouchi et al., 2004), teak (Varghese et al., 2008) as well as in seed orchards of teak (Bila et al., 1999; Varghese et al., 2006), Norway spruce (Nikkanen and Ruotsalainen, 2000), Pine species (Bilir et al., 2002; Kang et al., 2004) and Eucalyptus (Kamalakannan et al., 2007).

Monitoring of male and female fertility parameters over years would be useful in detecting the variations in seed production at a temporal scale which is an indicator of the influence of climatic factors in producing floral traits (Linhart and Mitton, 1985; Arista and Talavera, 1997; Koenig and Knops, 2000). Hence it could be suggested that it would be better to include more number of flowering seasons or years so that exact causes for variation could be easily envisaged while studying the year-effect on the growth and reproductive output of the tree species.

\section{Fertility variation}

Tree age, growth and location have long been recognized as crucial factors controlling fertility in several plants (Sedgley and Griffin, 1989; Crawley, 1997). Trees of A. leucophloea included in this study are mature representatives from arid and semi-arid environments where the annual rainfall is relatively low. Nevertheless, their flowering output is not constrained by the rainfall as the trees exhibit profuse flowering. This adaptation has been reported in several Acacias (Tandon et al., 2001; Solomon Raju et al., 2006). Like majority of the summer flowering Acacias (Milton and Moll, 1982; Tandon et al., 2001), A. leucophloea also flowers during rainy season particularly after monsoon.

In all stands, the female fertility was relatively higher than the male fertility. It clearly indicates that a larger proportion of flowers get aborted or fail to set fruits. This may be due to lack of fertilization or availability of legitimate pollinators. A similar condition has been encountered in natural stands of teak (Varghese et al., 2008). Moreover as reported earlier in several other Acacias (Moffett, 1956; Moran et al., 1989; Muona et al., 1991; Mandal and Ennos, 1995; Solomon Raju et al., 2006), 
A. leucophloea might have also adapted for outcrossing mechanism thereby increasing the risk of seed or fruit set. Thus, seed production in natural stands is a major constraint. In addition, information on seed biology such as seed viability, dormancy period and germination is not clearly understood. This would have a strong negative impact on stand practices as well as regeneration of new stands. Excessive fertility of a few trees can lead to relatedness among progenies and as a result there will be greater erosion in genetic diversity (Kang et al., 2004; Kamalakannan et al., 2007). Such a condition is not observed in the present study as an equal contribution was achieved in all four stands.

As a general thumb rule, Kang et al. (2003) suggested a sibling coefficient $(\psi)$ value of 2 for seed orchards and 3 in cases of natural stands. In the present study, all stands (except RKP) fitted well to the recommended value. Seed orchards, established with selected materials from several plus trees, are expected to provide large amounts of seeds with high genetic value (Ericksson et al., 1973). So it is obvious that these orchards to have $\psi$ value less than that of natural stands. In case of A. leucophloea, however, the $\psi$ value of natural stands was less than 2, which is recommended for seed orchards. Such a low fertility had been earlier reported in natural stands of conifers (Lindgren and Lindgren, 1976).

In the present investigation, the fertility variation has been monitored for only two successive years. Varghese et al. (2008) observed strong positive year-to-year correlations for various fertility parameters such as proportion of fertile trees, flowers and fruits produced per tree in natural stands of teak. In general, the teak flowering depends largely on rainfall and soil type. In this context, precipitation has nothing to do with flower production as A. leucophloea is a dry zone species. Whereas hermaphroditism associated with self-incompatible mechanism or delayed poor selfing (Tangmitcharoen and Owens, 1997), ageing of tree (Kang et al., 2004) and lack of silvicultural practices (e.g. thinning) might be reasons for the low variation of fertility across years in the stands of A. leucophloea.

\section{Effective population size and gene diversity}

Natural stands in general tend to have higher fertility variation and hence a low effective population size when compared to seed production areas or seed orchards. Varghese et al. (2008) had observed this in natural stands of teak. According to Pinyopusarerk and Hardwood (2003), seed collection could be done in orchards where $50 \%$ of trees are fertile. Though their estimates were based on the performance of Eucalyptus orchards, it could be considered as they were highly preferred in arid regions and had been established in several dry tracts of southern India. The present study indicated that TNL 1, TNL 2 and PDM could be considered for seed source stands as they had more than $50 \%$ of effectively contributing trees. Such a high status number $(N s)$ in species growing in arid regions is comparable with a high value reported by Kamalakannan et al. (2007) in seedling seed orchards of E. camaldulensis established in an arid zone.

Kamalakannan et al. (2015a) had observed a low parental contribution from individuals (only $20 \%$ ) in seed stands of two tropical species namely Tamarindus indica and Azadirachta indica. Hence it should be noted that even sometimes in seed stands, individuals exhibit a high deviation in gamete contribution owing to rainfall and other environmental conditions.

All stands showed a near equal value of coancestry while RKP recorded a little high value. Expected gene diversity decreases with increasing coancestry (Kang and Lindgren, 1999). But when comparing with values of gene diversity reported in the other orchard crops, A. leucophloea recorded relatively low coancestry values. The value of coancestry seems to be more relevant while discussing about the performance of orchard species.

\section{Low fruit set percentage}

Forest trees exhibiting lower fruit set is not a rare or unusual phenomenon and have been generously reported in several instances (Stephenson, 1981; Solomon Raju and Rao, 2002; Solomon Raju et al., 2006). Resource availability, pollen availability, predation, adverse climatic conditions and genetic factors may all act to constrain tree fertility (Charlesworth, 1989; Burd, 1994). Among these, first two receive more attention. Pollinator behavior and plant mating systems are influenced by a variety of plant traits including floral morphology, selfincompatibility and inflorescence architecture (Wyatt, 1982; Harder and Barrett, 1996; Richards, 1997). A. leucophloea recorded low fruit set in all four natural stands. In fact most of the individual trees exposed the inflorescence stalk clearly with no fruit set in them.

Based on the observations in the present study three possible reasons could be attributed for such a low fruit set. Flowers of A. leucophloea are tiny, borne in globose heads, each head consisting of sessile flowers. First, regarding the floral display it is not that much attractive. The flower is inconspicuous; colour is not distinct and almost resembled the bark colour of the tree. The flowers also do not have any particular odour. This may be one of the reasons that fail to attract legitimate pollinators or floral visitors for effective pollination, and this causes a low fruit set of A. leucophloea (Moran et al., 1989; Muona et al., 1991; Mandal and Ennos, 1995; Tandon et al., 2001). The poor information on the breeding system or pollination ecology of A. leucophloea eventually cultivates the problem which has to be investigated in detail in future studies.

The second probable reason for a low fruit set may be due to inbreeding. Not only isolated trees show low fruiting pattern but also trees in clusters exhibit very low or no fruiting at all. Due to lack of effective pollinators and at the end of flowering period, the plants may undergo certain level of selfing in which no fruit set could be observed sometimes. Moreover the tree age is a factor that determines flower production and fruit setting but the age of trees growing in studied natural stands are unknown.

The third reason for decreased fruit set is attributed by ants that feed on the flowers. It is evident that pollen grains produced by flowers are rich in nutrients. Pollen has carbohydrates and proteins as reserves. In addition, it possesses vitamins, minerals, coenzymes and sterols (Schmidt and Buchmann, 1992) and hence foraged by a wide range of 
pollinators. In case of $A$. leucophloea as pollen remains in clusters, ants feed on them much. The association of ants on individual trees was apparent in all natural stands that were included in this study. Ants collect even fresh flowers (freshly opened globose heads) and roll them to their hives that were mostly present beneath trees. Hence, it would be apt to describe them as resident foragers in this case. A noted ant-tree association had already been reported in case of A. sinuata (Solomon Raju and Rao, 2002) and in A. caesia (Solomon Raju et al., 2006).

\section{Implications on future management and breeding}

Evaluating the consequence of breeding operations in seed stands or natural populations requires predictions of fertility variation (Bila et al., 1999; Kang et al., 2003). However in most cases of tropical trees, this information does not exist. The present work may serve as the first report describing tree fertility of species based on the data collected on flowering abundance, fruit set and seed production in natural stands.

Despite it is a potential species to grow in dry locations, no progressive effort has been taken for assemblage of germplasm or rising in seed orchards. The one prominent reason may be the fact that it is a very slow growing long-lived tree. Though it produces secondary timber, the tree does not form clear bole and is generally of medium size. The tree also has prominent thorns. These are the facts that account for a general negligence. According to Suangtho et al. (1999), conservation stands are of great significance as they needed to conserve diversity for sustained improvement in advanced generations. This, in particular, is of more use for long-lived trees that have high fertility variation and hence a low fruit set.

Low fruit set in all natural stands indicates that this tree has inadequate pollination mechanisms. Based on the information on fertility variation, better performing stands can be identified at local scale for quality germplasm collection. Later these can be enhanced into seed stands through repeated management practices. Management practices would be as simple as it does not even need much irrigation. It is apparent from the present study that the waterlogged stand RKP was underperforming than the other three natural stands situated on dry patches, i.e. water has nothing to do with flowering or fruiting in this species.

Enhanced genetic gain through assemblage of elite genotypes is the main reason for establishing seed orchards (Kang and Lindgren, 1999). Equal collection of seeds from representative clones is one of the major strategies to increase the effective population size in a seed orchard. But this cannot be applied exactly to the natural stands. A. leucophloea does not produce coppice shoots and also cannot be regenerated through cuttings. This forms another major constraint in their natural regeneration. Moreover germination studies remains unavailable. Hence it can be suggested that plus trees can be identified in natural stands of $A$. leucophloea and seeds can be collected from them based on the data on fertility variation and seed production. These can be used for assembling elite or superior genotypes for sustained improvement as well as management of stands.
Based on the inputs of fertility variation and effective population size, the pure natural stands can serve directly as seed production areas followed by thinning. Kamalakannan et al. (2015b) had tried this option in a clonal trial of E. camaldulensis and worked out the possibility of converting into a clonal seed orchard. In their evaluation, it was recommended that the trial could be converted into a clonal seed orchard after selective thinning and the effective population size could be enhanced to $52 \%$ from the earlier $30 \%$ based on the fertility of retained trees.

\section{Acknowledgements}

We are grateful to Professor Emeritus Dag Lindgren, Swedish University of Agricultural Sciences and Dr. Mohan Varghese, Principal Scientist, ITC Ltd, ITC LSTC, Bangalore for their valuable comments and suggestions. This work was supported by Korea Institute of Planning and Evaluation for Technology in Food, Agriculture, Forestry and Fisheries (IPET) through Agri-Bioindustry Technology Development Program, funded by Ministry of Agriculture, Food and Rural Affairs (MAFRA) (No. 314009-3).

\section{References}

Arista M, Talavera S (1997) Gender expression in Abies pinsapo Boiss., a Mediterranean fir. Annals of Botany 79:337-342 http://dx.doi.org/10.1006/anbo.1996.0353

Bila AD, Lindgren D (1998) Fertility variation in Milletia stuhlmannii, Brachystegia spiciformis, Brachystegia bohemii and Leucaena leucocephala and its effects on relatedness in seeds. Forest Genetics 5:119-129

Bila AD, Lindgren D, Mullin TJ (1999) Fertility variation and its effect on diversity over generations in a teak plantation (Tectona grandis L.f.). Silvae Genetica 48:109-114

Bilir N, Kang KS, Ozturk H (2002) Fertility variation and gene diversity in clonal seed orchards of Pinus brutia, Pinus nigra and Pinus sylvestris in Turkey. Silvae Genetica 51:112-115

Burd M (1994) Bateman's principle and plant reproduction: the role of pollen limitation on fruit and seed set. Botanical Review 60:83-139 http://dx.doi.org/10.1007/bf02856594

Charlesworth D (1989) Why do plants produce so many more ovules than seeds? Nature 338:21-22 http://dx.doi.org/10.1038/338021a0

Cockerham CC (1967) Group inbreeding and coancestry. Genetics 56:89-104 Crawley MJ (1997) Plant Ecology (Second edition). Blackwell Science, Oxford, UK http://dx.doi.org/10.1002/9781444313642

Debain S, Curt T, Lepart J Prevosto B (2003) Reproductive variability in Pinus sylvestris in Southern France: implications for invasion. Journal of Vegetation Science 14:509-516

http://dx.doi.org/10.1111/j.1654-1103.2003.tb02177.x

Devlin B, Ellstrand NC (1990) Male and female fertility variation in wild radish, a hermaphrodite. American Naturalist 136:87-107 http://dx.doi.org/10.1086/285083

El-Kassaby YA, Cook C (1994) Female reproductive energy and reproductive success in a douglas-fir seed orchard and its impact on genetic diversity. Silvae Genetica 43:243-246

El-Kassaby YA (1995) Evaluation of tree-improvement delivery systems: factors affecting genetic potential. Tree Physiology 15:545-550 http://dx.doi.org/10.1093/treephys/15.7-8.545

Eriksson G, Jonsson A, Lindgren D (1973) Flowering in a clonal trial of Picea abies (Karst.). Studia Forestalia Suecica 110:4-45

Gregorious HR (1989) Characterization and Analysis of Mating Systems. Ekopan Verlag, Germany 
Gregorious HR, Muller G (1975) Genetic structures in finite, open-pollinated plant populations: a model and its applications to seed orchards. Theoretical and Applied Genetics 46:295-305

Harder LD, Barrett SCH (1996) Pollen dispersal and matting patterns in animal pollinated species. In: Lloyd DG \& Barrett SCH (eds) Floral biology: studies on floral evolution in animal-pollinated plants, Chapman and Hall, New York, USA, pp 140-190 http://dx.doi.org/10.1007/978-1-4613-1165-2_6

Kamalakannan R, Varghese M, Lindgren D (2007) Fertility variation and its implications on relatedness in seed crops in seedling seed orchards of Eucalyptus camaldulensis and E. tereticornis. Silvae Genetica 56:253-259

Kamalakannan R, Varghese M, Park JM, Kwon SH, Song JH, Kang KS (2015a) Fertility variation and its impact on effective population size in seed stands of Tamarindus indica and Azadirachta indica. Silvae Genetica 64(3):91-99

Kamalakannan R, Varghese M, Suraj PG, Arutselvan T (2015b) Options for converting a clone trial of Eucalyptus camaldulensis into a clonal seed orchard considering gain, fertility and effective clone number. Journal of Forestry Research 27:51-57 http://dx.doi.org/10.1007/s11676-015-0169-y

Kang KS, Lindgren D (1998) Fertility variation and its effect on the relatedness of seeds in Pinus densiflora, Pinus thunbergii and Pinus koraiensis clonal seed orchards. Silvae Genetica 47:196-201

Kang KS, Lindgren D (1999) Fertility variation among clones of Korean pine (Pinus komiensis S. et Z.) and its implications on seed orchard management. Forest Genetics 6:191-200

Kang KS, Bila AD, Harju AM, Lindgren D (2003) Estimation of fertility variation in forest tree populations. Forestry 76:329-344 http://dx.doi.org/10.1093/forestry/76.3.329

Kang KS, Lindgren D, Mullin TJ (2004) Fertility variation, genetic relatedness and their impacts on gene diversity of seeds from a seed orchard of Pinus thunbergii. Silvae Genetica 53:202-206

Koeing WD, Knops JMH (2000) Patterns of annual seed production by northern hemisphere trees: a global perspective. American Naturalist 155:59-69 http://dx.doi.org/10.1086/303302

Krouchi F, Derridj A, Lefevre F (2004) Year and tree effect on reproductive organization of Cedrus altlantica in a natural forest. Forest Ecology and Management 197:181-189 http://dx.doi.org/10.1016/j.foreco.2004.05.013

Lacy RC (1995) Clarification of genetic terms and their use in the management of captive populations. Zoo Biology 14:565-578 http://dx.doi.org/10.1002/zoo.1430140609

Lindgren D, Lindgren K (1976) The effective population number in a Picea abies (Karst) seed orchard based on flower assessment. Scandinavian Journal of Forest Research 11:111-121

Lindgren D, Mullin TJ (1998) Relatedness and status number in seed orchard crops. Canadian Journal of Forest Research 28:276-283 http://dx.doi.org/10.1139/cjfr-28-2-276

Lindgren D, Gea LD, Jefferson PA (1996) Loss of genetic diversity monitored by status number. Silvae Genetica 45:52-59

Linhart YB, Mitton JB (1985) Relationships among reproduction growth rates and protein heterozygosity in ponderosa pine. American Journal of Botany 72: $181-184$ http://dx.doi.org/10.2307/2443545

Mandal AK, Ennos AK (1995) Mating system analysis in a natural population of Acacia nilotica subsp. kraussiana. Forest Ecology and Management 79:235240 http://dx.doi.org/10.1016/0378-1127(95)03542-7

Milton SJ, Moll EJ (1982) Phenology of Australian acacias in S.W. Cape, South Africa, and its implications for management. Botanical Journal of the Linnean Society $84: 295-327$ http://dx.doi.org/10.1111/j.1095-8339.1982.tb00367.x

Moffett AA (1956) Genetical studies in acacias. I. The estimation of natural crossing in black wattle. Heredity 10:57-67 http://dx.doi.org/10.1038/hdy.1956.4

Moran GF, Muona O, Bell JC (1989) The breeding systems and genetic diversity in the tropical Acacias, Acacia auriculiformis and A. crassicarpa. Biotropica 21:250-256 http://dx.doi.org/10.2307/2388652
Muona O, Moran GF, Bell JC (1991) Hierarchical patterns of correlated mating in Acacia melanoxylon. Genetics 127:619-626

Nei M (1973) Analysis of gene diversity in subdivided populations. Proceedings of the National Academy of Sciences 70:3321-3323 http://dx.doi.org/10.1073/pnas.70.12.3321

Nikkanen T, Ruotsalainen S (2000) Variation in flowering abundance and its impact on the genetic diversity of the seed crop in a Norway spruce seed orchard. Silva Fennica 34:205-222 http://dx.doi.org/10.14214/sf.626

Nunney L (2000) The limits to knowledge in conservation genetics-the value of effective population size. Evolutionary Biology 32:179-194 http://dx.doi.org/10.1007/978-1-4615-4135-6_9

Parotta JA (2001) Healing plants of peninsular India. CABI Publishing, USA.

Pinyopusarerk K, Harwood CE (2003) Flowering and seed production in tropica Eucalyptus seed orchards. In: Turnbull JW (ed) Eucalypts in Asia. ACIAR proceedings No. 111,Australian Centre for International Agricultural Research, Canberra, pp 247-248

Richards AJ (1997) Plant Breeding Systems (Second edition). Chapman and Hill Publishers, 2-6 Boundary Row, London SE1 8HN, UK http://dx.doi.org/10.1007/978-1-4899-3043-9

Schmidt JO, Buchmann SL (1992) Other products of the hive. In: Graham JM (ed) The hive and the honeybee, Dadant \& Sons, Hamilton, Illinois, USA, pp 927 988

Sedgley M, Griffin AR (1989) Sexual reproduction in tree crops. Academic Press, London

Solomon Raju AJ, Rao PS (2002) Pollination ecology and fruiting behaviour in Acacia sinuata (Lour.) Merr. (Mimosaceae), a valuable non-timber forest plant species. Current Science 82:1466-1471

Solomon Raju AJ, Rao PS, Henry Jonathan K (2006) Andromonoecy, insect pollination and fruiting behaviour in Acacia caesia (L.)Willd. (Mimosaceae) in the Eastern Ghats. Current Science 91:939-943

Stephenson AG (1981) Flower and fruit abortion: proximate causes and ultimate functions. Annual Review of Ecology, Evolution and Systematics 12:253-279 http://dx.doi.org/10.1146/annurev.es.12.110181.001345

Suangtho VL, Graudal L, Kjaer ED (1999) Genecological zonation as a tool in conservation of genetic resources of Teak (Tectona grandis) in Thailand. In: Teak Beyond 2000. Proceedings of the International Teak Conference. 23-25 August, Chiang Mai, Thailand, pp 1-8

Tandon R, Shivanna KR, Mohan Ram HY (2001) Pollination biology and breeding system of Acacia senegal. Botanical Journal of the Linnean Society 135:251262 http://dx.doi.org/10.1111/j.1095-8339.2001.tb01094.x

Tangmitcharoen S, Owens JN (1997) Floral biology, pollination, pistil receptivity and pollen tube growth of teak (Tectona grandis Linn f.). Annals of Botany 79:227-241 http://dx.doi.org/10.1006/anbo.1996.0317

Varghese M, Kamalakannan R, Nicodemus A, Lindgren D (2008) Fertility variation and its impact on seed crops in seed production areas and a natural stand of teak in southern India. Euphytica 160:131-141 http://dx.doi.org/10.1007/s10681-007-9591-3

Varghese M, Nicodemus A, Nagarajan B, Lindgren D (2006) Impact of fertility variation on gene diversity and drift in two clonal seed orchards of teak (Tectona grandis Linn. f.). New Forests 31:497-512 http://dx.doi.org/10.1007/s11056-005-2178-8

Vasudeva R, Hanumantha M, Gunaga RP (2004) Genetic variation for floral traits among teak (Tectona grandis Linn.f) clones: Implications to seed orchard fertility. Current Science 87:358-362

Wyatt R (1982) Inflorescence architecture: how flower number, arrangement, and phenology affect pollination and fruit set. American Journal of Botany 69:585-594 http://dx.doi.org/10.2307/2443068 